\title{
Nilai Moralitas dalam Pembentukan Peraturan Perundang-Undangan
}

\begin{tabular}{|c|c|}
\hline \multicolumn{2}{|c|}{ Fakultas Hukum Universitas Pekalongan, Indonesia } \\
\hline Info Artikel & Abstract \\
\hline \multirow[t]{2}{*}{$\begin{array}{l}\text { Keywords: } \\
\text { Morality; Legislation; } \\
\text { Regulation. }\end{array}$} & $\begin{array}{l}\text { The legislators should make the value of Pancasila a fundamental } \\
\text { value or as the source of all sources of law, bringing consequences } \\
\text { for the legislators to become a guide and guide in carrying out } \\
\text { legislative functions. Ironically, the reality is that the legislators } \\
\text { show that there are paradigmatic problems and a crisis of ethical } \\
\text { awareness in the formation and enforcement of laws in Indonesia. } \\
\text { What emerges is law development and law enforcement that is } \\
\text { stagnant, centralized, corrupt and very far from divine and } \\
\text { humanist values, and far from achieving social justice. The } \\
\text { actualization of Divine Values as the fundamental value of } \\
\text { Pancasila should be accommodated and become the basis for } \\
\text { legislators in carrying out their functions and duties in the } \\
\text { formation of laws or laws and transformed into laws that they } \\
\text { form, so that they will give birth to laws that are effective and have } \\
\text { divine dimensions. humanity, unity and social justice. }\end{array}$ \\
\hline & Abstrak \\
\hline $\begin{array}{l}\text { Kata kunci: } \\
\text { Moralitas; Legislasi; Peraturan. }\end{array}$ & $\begin{array}{l}\text { Pembentuk Peraturan Perundang-undangan (legislator) sedah } \\
\text { seharusnya menjadikan nilai Pancasila sebagai fundamental nilai } \\
\text { atau sebagai sumber dari segala sumber hukum, membawa } \\
\text { konsekwensi bagi pembentuk Peraturan Perundang-Undangan } \\
\text { untukmenjadi penuntun dan pedoman dalam menjalankan fungsi }\end{array}$ \\
\hline $\begin{array}{l}\text { Corresponding Author: } \\
\text { Suryani, E-mail: } \\
\text { suryani.unikal@gmail.com }\end{array}$ & $\begin{array}{l}\text { legislasi. Ironisnya, realitasnya Pembentuk Undang-undang } \\
\text { justru memperlihatkan adanya problematika paradigmatik dan } \\
\text { krisis kesadaran etis dalam pembentukan dan penegakan hukum } \\
\text { di Indonesia. Sehingga yang muncul adalah pembangunan hukum }\end{array}$ \\
\hline P-ISSN: 1412-6605 & dan penegakan hukum yang stagnan, sentralistik, koruptif dan \\
\hline E-ISSN: $2301-6426$ & $\begin{array}{l}\text { sangat jauh dari nilai-nilai Ketuhanan dan humanis, dan jauh dari } \\
\text { tercapainya keadilan sosial. Aktualisasi Nilai Ketuhana sebagai } \\
\text { nilai fundamental dari Pancasila seharusnya diakomodir dan } \\
\text { menjadi landasan bagi legislator dalam menjalankan fungsi dan } \\
\text { tugasnya dalam pembentukan hukum atau undang-undang dan } \\
\text { di transformasikan dalam produk undang-undang yang } \\
\text { dibentuknya, sehingga akan melahirkan undang-undang yang } \\
\text { efektif dan berdemensi ketuhanan, kemanusian, persatuan dan } \\
\text { berkeadilan social. }\end{array}$ \\
\hline
\end{tabular}

\section{Pendahuluan}

Pembangunan di bidang hukum harus berdasar atas landasan cita-cita yang terkandung pada pandangan hidup, kesadaran dan cita-cita moral yang luhur yang meliputi suasana kejiwaan serta watak dari bangsa Indonesia yang ditemukan dalam Pancasila dan UUD 1945. Hukum sebagai pengaturan 
perbuatan-perbuatan manusia yang dibuat oleh kekuasaan yang sah, bukan hanya berupa keputusan melainkan juga dalam pelaksanaannya sesuai dengan ideologi bangsa yang bersangkutan, sebagai pengayom bangsa yang institusional, berdasarkan hukum alam. ${ }^{1}$

Indonesia sebagai negara hukum (welfare state) sebagai bentuk negara, maka setiap tindakan dan akibatnya yang dilakukan pemerintah dan badan legislative pihak harus didasarkan dan diselesaikan menurut hukum. Secara tidak langsung, semua hal akan disandarkan kepada Pancasilas sebagai ideologi bangsa. Ekosistem hukum juga banyak tergantung kepada faktor-faktor yang berada di luar hukum, artinya hukum bukan sesuatu yang supreme. Adanya hukum karena adanya kepentingan politik, ekonomi, sosial, budaya dan lainlain. Siapa yang paling banyak terlibat di dalam pembentukan hukum adalah para elit utama negara, sehingga terkadang orientasi hukumnya bersifat elitis dan selalu melindungi dan membela kepentingan mereka.

Pancasila sebagaimana tercantum di dalam pembukaan UUD 1945 merupakan kesatuan yang bulat dan utuh dari kelima sila, yaitu Ketuhanan Yang Maha Esa, kemanusiaan yang adil dan beradab, persatuan Indonesia, kerakyatan yang dipimpin oleh hikmat kebijaksanaan dalam permusyawaratan /perwakilan, dan keadilan sosial bagi seluruh rakyat Indonesia. Ini berarti bahwa dalam pembangunan hukum nasional pada hakikatnya adalah membangun konsep-konsep tatanan yang beroriantasi pada nilai-nilai Pancasila, yaitu moral religius (ketuhanan), humanistik (kemanusiaan), nasionalistik/ persatuan (kebangsaan), demokrasi (kerakyatan) dan keadilan sosial. Penempatan 'Ketuhanan Yang Maha Esa' sebagai sila pertama Pancasila berimplikasi pada adanya pergeseran perspektif dalam memaknai ilmu hukum Indonesia; dari ilmu hukum yang berbasis pada akal-budi manusia ke ilmu hukum yang bersandar pada nilai-nilai ketuhanan ${ }^{2}$, termasuk pula dalam kontek pembentukan peraturan perundang-undangan. Adanya pergeseran perspektif tersebut menuntut adanya usaha ilmiah untuk menggali dan menemukan ilmu hukum berketuhanan yang merupakan ciri khas ilmu hukum Indonesia dengan menekankan pada sisi ontologi, epistemologi, dan aksiologinya.

Pembangunan hukum nasional yang berorientasi pada nilai-nilai moral religius dapat dipahami bahwa nilai-nilai moral luhur yang telah membumi di Indonesia harus dijadikan sebagai titik pijakan dalam merumuskan kebijakan hukum nasional. Hal ini berarti bahwa nilai-nilai moral luhur yang mengakar dan membumi di Indonesia diwarnai oleh nilai-nilai religius yang transenden

\footnotetext{
${ }^{1}$ Mahrus Ali, "Fondasi Ilmu Hukum Berketuhanan: Analisis Filosofis terhadap Ontologi, Epistemologi, dan Aksiologi", Pandecta Jurnal, Volume 11. Nomor 2. December 2016, hal 74 ${ }^{2}$ Ibid.
} 
yaitu ajaran Islam. ${ }^{3}$ Pancasila tidak ada yang berbenturan dengan ajaran agama. Bahkan, dengan mengimplementasikan nilai Pancasila dalam kehidupan berbangsa dan bernegara dapat dipahami sebagai wujud pengamalan ajaran agama dalam konteks ke Indonesiaan. Di dalam masyarakat yang menganut tradisi hukum Civil Law, undang-undang merupakan sumber hukum yang utama sehingga dengan demikian, terbentuknya suatu sistem hukum dipengaruhi oleh proses pembentukan undang-undang.

Proses pembentukan peraturan perundang-undangan di Indonesia acapkali menghasilkan suatu peraturan perundang-undangan yang kontroversial, dan terjadi penolakan dan ujungnya adanya banyak undang-undang begitu diuundangkan sertamerta pula diajuakan yudisial review ke Mahkamah Konstitusi. Berbagai polemik undang-undang yang dihasilkan seringkali dipandang hanya untuk kepentingan pihak tertentu, mengabaikan hak dan perlindungan bagi pihak yang dianggap berkedudukan lemah, serta dinilai tidak sesuai dengan nilai-nilai keutamaan yang dianut dalam masyarakat, 4 dan bertentangan dengan nilai-nilai Pancasila dan konstkonstitusi. ${ }^{5}$ Banyaknya norma yuridis yang dieksminasi ini juga mengindikasikan terjadi kelemahan konstruksi sistem hukum nasional. Pembatalan sejumlah produk Peraturan Daerah dan banyaknya Mahkamah Konstitusi (MK) dalam menerima permohonan judicial review, juga mengindikasikan kebenaran kalau produk peraturan perundang-undangan mengandung kelemahan serius. Oleh sejumlah ahli, kelemahan ini tidak lepas dari kurangnya mempertimbangkan atau "mengistimewakan" Pancasila sebagai sumber rujukan utama dalam pembentukannya. Oleh karena itu, sudah saatnya sekarang kalangan pembantuk peraturan perundang-undangan fokus menjadikan Pancasila sebagai pertimbangan asasinya. ${ }^{6}$

Mahfud MD sebagaimana dikutip Rahel Octora “Banyak Rancangan UndangUndang yang spontan dan tidak ada urgensinya. Sampai saat ini masih banyak 'kegenitan' politisi kita dalam pengajuan pembentukan undang-undang. Selain itu banyak juga RUU yang bermasalah, apakah itu rancu secara substansi, saling tumpang tindih dengan peraturan lain, atau tidak memiliki konsistensi." 7 Banyaknya produk norma hukum yang dipermasalahkan atau diuji oleh banyak

${ }^{3}$ Noer, Deliar, 1980, Gerakan Modern Islam di Indonesia 1900-1942, Jakarta, LP3ES, 1980: 4

${ }_{4}^{4}$ Abdul Kadir Jaelani, I Gusti Ayu Ketut Rachmi Handayani, Lego Karjoko. The Political Law of the Constitutional Court In Canceling the Concept of the Four Pillars as an Pancasila as the State Foundation, Talent Development E Excellence, Vol.12, No.2s, 2020.

${ }^{5}$ Ibid

6Zaidah Nur Rosidah, "Coherence of the Rules of Sharia Against Pancasila", Bestuur, Volume 8, Nomor 1 Tahun 2020.

${ }^{7}$ Lego Karjoko, Zaidah Nur Rosidah, I Gusti Ayu Ketut Rahmi Handayani “Refleksi Paradigma Ilmu Pengetahuan Bagi Pembangunan Hukum Pengadaan Tanah", Bestuur, Volume 7, Nomor 1 Tahun 2019. 
pihak, adalah satu masalah serius dalam politik pembaruan hukum nasional. ${ }^{8}$ Dalam ranah demikian, salah satu pihak yang seharusnya merasa digugat keseriusan dalam membentuk atau memproduksinya adalah badan legislatif. Kondisi tersebut mengindikasikan bahwa legislator dalam menjalankan tugas dan kewenanganaya dipengaruhi berbagai factor antara lain mengabaikan mora etis (nilai Ketuhanan), kapasitas legislator dan mengabaikan konsep pembentukan undang-undang sebagaimana diatur dalam Undang-Undang Nomor 12 Tahun 2011. ${ }^{9}$ Tulisan ini akan membahas pentingnya sikap dan prilaku moral etis legislator dalam proses pembentukan hukum di Indonesia. Adapun hal-hal yang akan dibahas adalah bagaimana moral etis diperankan legislator dalam proses pembentukan hukum di Indonesia dapat dilakukan secara konkrit dalam rangka menghasilkan peraturan perundang-undangan yang baik.

\section{Metode Penelitian}

Penelitian ini merupakan penelitian hukum normatif karena yang dikaji adalah Nilai Ketuhanan dalam pembentukan peraturan perundang-undangan, focus kajiannya diarahkan pada paradigm dan prilaku subyek pembentuknya (legislator). Pendekatan yang digunakan adalah pendekatan filosofis, dan konseptual. Bahan hukum dikumpulkan melalui studi literatur. Sedangkan analisis penelitian dilakukan secara deskriptif kualitatif, dalam arti bahan hukum diuraikan dalam bentuk narasi yang tersusun secara sistematis, logis, dan merupakan hasil dari proses inter pretasi peneliti terhadap bahan hukum yang dihasilkan. ${ }^{10}$

\section{Hasil dan Pembahasan}

\section{Paradigma Pembentuk Undang-Undang}

Bagi anggota Dewan Perwakilan Rakyat sebagai representasi rakyat mempunyai fungsi, salah satunya adalah fungsi pembentukan peraturan perundang-undangan (fungsi legislasi), produk undang-undang tersebut tentunya mencerminkan falsafah dan pandangan hidup bangsa Indonesia yaitu Pancasila yang memiliki dan mengandung nilai dan roh transenden. Menghadirkan nilai ketuhanan tersebut dalam dinamika pembentukan hukum mulai dari proses perencanaan RUU, (penyusunan Naskah Akademik,

${ }^{8}$ I Gusti Ayu Ketut Rachmi Handayani, Lego Karjoko, Abdul Kadir Jaelani, “Model Pelaksanaan Putusan Mahkamah Konstitusi yang Eksekutabilitas Dalam Pengujian Peraturan Perundang-Undangan di Indonesia", Bestuur, Volume 7, Nomor 1 Tahun 2019.

${ }^{9}$ Ibid.

10Siti Fatimah, Iswantoro, Udiyo Basuki, Rian Saputra, The Public Policy Of Local Government In Protecting Geographic Indication As A Leading Regional Product, International Journal of Advanced Science and Technology Vol. 29, No. 4, (2020). 
pembahasan RUU di DPR) dan pada saat pengesahan sampai pada proses penegakan hukum selalu dimulai dengan kalimat Tuhan yaitu "Dengan Rahmat Tuhan Yang Maha Esa" dalam setiap produk hukum sebagai syarat formil dan juga demi keadilan berdasarkan keTuhanan Yang Maha Esa dalam setiap keputusan hakim sebagai irah-irah putusan sebagai jalan mencapai Tuhan. ${ }^{11}$

Surono dan Huda menyatakan, Dalam ilmu hukum berketuhanan, hukum dimaknai sebagai nilai. Nilai di sini adalah nilai-nilai ketuhanan yang digali dari nilai-nilai agama, nilai kepercayaan dan nilai- nilai budaya masyarakat Indonesia, yang bentuknya berupa nilai religius, nilai kemanusiaa, nilai persatuan, nilai demokrasi, dan nilai keadilan sosial ${ }^{12}$ Ada fenomena menarik di kancah penegakan hukum dan politik pembaruan hukum nasional. Dalam demensi praksis subyek pembentuk hukum dalam hal ini legislative telah kehilangan bijakan utamnaya telah terjadi pengabaian oleh para legislator terhadap nilai Pancasila utamnaya Nilai Ketuhanan, mereka pengembang amanant konstitusi untuk membentuk undang-undang mengedepankan kepentinagan politik dan ekonomi yang berparadigma positivistic berwatak kapitalisme , sehingga Kesalahan atau kekeliruan dalam aspek produk norma yuridis akan menjadi sangat berbahaya, sehinga logis jika dari sisi ini, muncul banyak gugatan publik. Hal ini sebagaimana pandangan Mahfud MD bahwa terdapat problem serius yang melanda pembentukan dan penegakan hukum di Indonesia, hukum dibuat dan ditegakkan seolah kehilangan nyawa, hukum dengan mudah dirasuki oleh kepentingan sesaat yang justru bertentangan dengan cita dan tujuan hukum (Pancasila). ${ }^{13}$

Akibat serius itu adalah Undang-Undang atau produk legislatif ini belum sepenuhnya menjadi kekuatan normatif yang mengayomi dan melindungi masyarakat dan jauh dari nilai-nilai Pancasila. Pancasila sebagai rechtsidee belum sepenuhnya diposisikan sebagai suatu cita hukum yang mengarahkan Undang-Undang atau produk legislatif untuk memenuhi keadilan substantif yang dicita-citakan oleh masyarakat. Keadilan substantif menjadi hal yang semakin sulit diperoleh akibat produk yuridisnya yang dihasilkan oleh legislator yang abai dan menafikan nilai -nilai Pancasila, terutama moral relegius dalam menjalankan tugas legislasinya. Realitasnya antara das sain dan das sollen terjadi kesenjangan, banyak produk undang-undang termasuk undang-undang terindikasi banyak yang tidak mencerminkan nilai-nilai Pancasila, salah satunya nilai Ketuhanan Yang Maha Esa. Beberapa faktor

\section{${ }^{11}$ Ibid.}

${ }^{12}$ Ibid.

${ }^{13}$ Ach.Tahir, Iswantoro, Siti Fatimah, Resti Dian Luthviati, Rian Saputra, Abdul Kadir Jaelani, The Model Of Criminal Policy To Customary Law Society After Decision Of The Constitutional Court Of The Republic Of Indonesia Number 95/PUU-XII/2014, International Journal of Advanced Science and Technology Vol. 29, No. 4, (2020). 
yang menyebabkan belum terinternalisasinya Pancasila utamanya sila pertama ( nilai Keuhanan ) dalam pembentukan peraturan perundangundangan pada dasarnya disebabkan karena fungsi legislasi selama ini dikesampingkan, dan menonjolkan politik mayoritas, orientasi pertumbuhan ekonomi dan watak antroposentris menjadi dasar pemikiran para pembuat peraturan perundang-undangan (bukan ukuran-ukuran nilai filosofis ideal dan konstitusional), kualitas anggota yang mengacu pada pengetahuan dan pengalaman, perilaku korupsi legislasi dan ketiadaan dokumen negara yang resmi terkait penjabaran nilai-nilai Pancasila. ${ }^{14}$

Anggota DPR sebagai subyek pembentuk hukum, sangat dipengaruhi oleh paradigma dan atau pendekatan dalam berhukum, apakah positivistik, postpositivistik atau pendekatan hukum berbasis religiusitas atau profetik. Ilmu hukum yang dijalankan melalui pembentukan undang-undang dalam praktiknya didominasi oleh pendekatan positifistik yakni yang kemudian menjadi hukum positif (ius contitutum) regulasi atau konkritnya undangundang. Sangat kecil kemungkinan seorang wakil rakyat bisa menyuarakan aspirasi para pemilihnya secara utuh. Lebih jauh, dalam kenyataan politis, kepentingan individu wakil rakyat inilah yang terasa lebih dominan mengemuka. Serentetan kasus korupsi wakil rakyat di negeri ini, baik di pusat maupun di daerah, bukti nyata bahwa kaitan antara "wakil rakyat ${ }^{\text {ee }}$ dengan "rakyat yang diwakilie tidak bisa diandaikan begitu saja. ${ }^{15}$

\section{Nilai Ketuhanan sebagai Penuntun dan Pedoman Bagi Legislator dalam Pembentukan Peraturan Perundang-Undangan}

Membahas peraturan perundang-undangan tentu saja tidak bisa dipisahkan selain membahas para aktor pembentuknya yaitu eksekutif, legislatif dan masyarakat ${ }^{16}$, Berkaitan dengan actor pembentukan undanguindang tersebut, maka pembentukan undang-undang atau pemegang perannya antara lain: (1) Elit formal seperti elit politik yang menurut konstitusi dan peraturan perundang-undangan mempunyai kewenangan membuat keputusan politik, dalam hal ini adalah eksekutif dan legislatif. Pihak yang mempunyai akses dalam membuat keputusan politik, antara lain, yaitu: (2) Elite strategis yaitu mereka yang memiliki sumber-sumber kekuasaan seperti, kekayaan, ilmu pengetahuan dan teknologi, tokoh

\footnotetext{
14 Bayu Dwi Anggono, Perkembangan Pembentukan Undang-Undang di Indonesia, Jakarta: Konstitusi Press, 2014, hlm. 771.

15Ibid., hlm. 7-8

16Pasal 70 Undang-Undang Nomor 17 Tahun 2014 tentang majelis permusyawaratan rakyat, dewan perwakilan rakyat, dewan perwakilan daerah, dan dewan perwakilan rakyat daerah (1) Fungsi legislasi sebagaimana dimaksud dalam Pasal 69 ayat (1) huruf a dilaksanakan sebagai perwujudan DPR selaku pemegang kekuasaan membentuk undang-undang.
} 
masyarakat / tokoh adat / pemimpin agama. ${ }^{17}$ (3) Penguasa yaitu orang yang berpengaruh karena mempunyai kedudukan non formal dalam masyarakat seperti 'local strongman' atau 'local bosism'. 18 Pembuatan undang-undang (Aktor: Legislator) tersebut tentunya tidak saja dipandang sebagai manusia bebas akan tetapi manusia dengan beragam kepercayaan dan keyakinan yang dianutnya atau juga latar belakang para aktor dari aspek keagamaan, keyakinan dan budaya sosial mereka, atas dasar keyakinan, dan budaya dan paradigma masing-masing akan sangat berpengaruh akan hasil keputusannya.

Legislasi dalam perspektif teoretis dan praktis dapat dilakukan dengan indikator-indikator yang terukur. Indikator tersebut untuk menunjukkan kualitas legislasi yang senyatanya. Indikator tersebut antara lain ${ }^{19}$ : Metodologi legislasi (legislative methodology), yaitu berkaitan dengan substansi legislasi, metodologi yang dapat digunakan untuk mengelaborasi substansi normatif. (2) Teknik legislasi (legislative technique), berkaitan dengan mengukur kualitas legislasi dari aspek formalnya - misalnya struktur dalam substansi undang-undang. (3) Perancangan legislasi (legislative drafting), berkaitan dengan mengukur kualitas legislasi dari perumusan norma dalam undang-undang. (4) Komunikasi legislasi (legislative communication), berkaitan dengan mengukur kualitas legislasi dari bagaimana cara mengkomunikasikan substansi normatif suatu peraturan. (5) Prosedur legislasi (legislative procedure), berkaitan dengan mengukur kualitas legislasi dengan melihat proses pembahasan, pengundangan, dan implementasi suatu peraturan. (6) Manajemen legislasi (the management of legislation), berkaitan dengan mengukur kualitas legislasi dengan melihatnya sebagai bagian dari suatu perencanaan peraturan perundang-undangan. Dalam konteks Indonesia, kategori ini melihat kualitas suatu undang-undang dengan mengukurnya dari Program Legislasi Nasional (Prolegnas) yang telah ditetapkan. (7) Aspek sosiologis dalam legislasi (the sociology of legislation), yaitu mengukur kualitas legislasi dengan melihat proses politik dalam pembahasan, pengundangan, proses implementasi, dan juga efek dari legislasi dari perspektif sosiologis. (8) Teori legislasi (the theory of legislation), yaitu mengukur kualitas legislasi dengan melihat fungsi legislasi sebagai instrument panduan sosial dan kontrol dari negara.

Berkaitan dengan moralitas Ketuhanan bagi penyelenggara Negara (legislator dan subyek lainnya), pendiri bangsa Soekarno memberikan penegasan: tidak ada suatu bangsa dapat berhebat, jikalau batinnya tidak terbuat dari nur iman yang sekuat-kuatnya. Jikalau kita bangsa Indonesia

17Simposium Nasional Pancasila Badan Keahlian DPR RI | 2016, hal. 41

${ }^{18}$ Valina Singka Subekti. Dinamika Konsolidai Demokrasi: Dari Ide Pembaruan Sistem Politik hingga ke Praktik Pemerintahan Demokratis. Jakarta: Yayasan Obor, 2015.

${ }^{19}$ Luzius Mader, "Evaluating the Effect: A Contribution to the Quality of Legislation," Loc. Cit. 
ingin kekal, kuat, nomor satu jiwa kita harus selalu jiwa yang ingin mi'raj ke atas, supaya kebudayaan kita naik ke atas, supaya negara kita naik ke atas. Bangsa yang tidak mempunyai adreng, adreng untuk naik ke atas, bangsa yang demikian itu, dengan sendirinya akan gugur pelan-pelan dari muka bumi (sir ilang kertaning bumi ). ${ }^{20}$

Penyataan Soekarno tersebut mengandung makna yang dalam bagi para pengembang hukum (legislator) bahwa di balik itu ada muatan-muatan kontekstual berdimensi luas ketika kita berbicara tentang pembentukan hukum, pernyataan tersebut mengandung ajakan proses transformasional dari arah dan tujuan yang ingin dicapai dan berdimensi luas, salah satunya adalah tranformasi nilai dan roh transenden menjadi strategis guna membangun hukum yang berkeadilan dan memberi kemanfaatan sekaligus memberi kepastian. Karena itu setiap penyusunan peraturan perundangundangan harus memperhatikan cita-cita moral dan cita-cita hukum sebagaimana diamanatkan di dalam konstitusi.

Nilai filosofis dan konstitusional tersebut, bagi para legislator menjadi pegangan dan keyakinan untuk diaktualisasikan dalam proses pembentukan undang-undang. Selain itu sebenarnya bagi setiap anggota DPR, pada saat pencalonan, pengambilan sumpah dan pada saat menjalankan fungsi dan tugasnya diliputi semangat ketuhanan atau etis profetik adalah sebagai berikut:

a. Frasa "Dengan Rahmat Tuhan Yang Maha Esa “21 menunjukkan satu hal yang sangat penting dan mendasar bahwa tugas legislator adalah tugas yang sangat luhur sebagai penegak hukum dan keadilan yang wajib dipertanggungjawabkan, utamanya kepada Tuhan Yang Maha Esa, yang sudah tentu untuk mencapainya dipersyaratkan sifat-sifat yang harus dimiliki oleh seorang legislator.

b. Syarat menjadi anggota Dewan Perwakilan Rakyat: salah satunya beriman dan bertaqwa kepada Tuhan.

${ }^{20}$ Yudi Latif, Negara Paripurna, Historitas, Rasionalitas, dan Aktualitas Pancasila, PT Gramedia Pustaka Utama, Jakarta, hlm. 613-614

${ }^{21}$ Undang-undang no 12 tahun 2011 jo Undang-Undang No 15 tahun 2019 tentang Pembentukan Peraturan Perundang-undangan telah menetapkan bahwa teknik penyusunan Peraturan perundang-undangan yang diatur pada Pasal 64 (1) Penyusunan Rancangan Peraturan Perundang-undangan dilakukan sesuai dengan teknik penyusunan Peraturan Perundangundangan. (2) Ketentuan mengenai teknik penyusunan Peraturan Perundang-undangan sebagaimana dimaksud pada ayat (1) tercantum dalam Lampiran II yang merupakan bagian tidak terpisahkan dari Undang-Undang ini. (3) Ketentuan mengenai perubahan terhadap teknik penyusunan Peraturan Perundang-undangan. Dalam Lampiran II undang-undang no 12 tahun 2011, sebagaimana dimaksud pasal 64 menetapkan setelah Judul Undang-undang diikuti dengan Frasa "Dengan Rahmat Tuhan Yang Maha Esa ". 
c. Sumpah anggota DPR, Pada saat akan diangkat menjadi Anggota Dewan Perwakilan Rakyat, harus mengucapkan sumpah atau janji dengan kalimat: "Demi Allah / Tuhan "saya bersumpah / berjanji,

d. Kewajiban Anggota DPR, Pada saat menjalankan tugas anggota DPR juga terikat pada kewajiban yang diatur dalam pasal 81 UU No. 17 Tahun 2014 jo UU No. 2 Tahun 2018 tentang Perubahan Kedua atas UU No. 17 Tahun 2014 tentang MD3 Undang-Undang Nomor 13 Tahun 2019 tentang Perubahan Ketiga atas Undang-Undang Nomor 17 Tahun 2014 tentang Majelis Permusyawaratan Rakyat, Dewan Perwakilan Rakyat, Dewan Perwakilan Daerah, dan Dewan Perwakilan Rakyat Daerah. Kewajiban Anggota Pasal 81 Anggota DPR berkewajiban: a. memegang teguh dan mengamalkan Pancasila; b. melaksanakan Undang-Undang Dasar Negara Republik Indonesia Tahun 1945 dan menaati ketentuan peraturan perundang-undangan; c. mempertahankan dan memelihara kerukunan nasional dan keutuhan Negara Kesatuan Republik Indonesia; d. mendahulukan kepentingan negara di atas kepentingan pribadi, kelompok, dan golongan; e. memperjuangkan peningkatan kesejahteraan rakyat; f. menaati prinsip demokrasi dalam penyelenggaraan pemerintahan negara; g. menaati tata tertib dan kode etik; h. menjaga etika dan norma dalam hubungan kerja dengan lembaga lain; i. menyerap dan menghimpun aspirasi konstituen melalui kunjungan kerja secara berkala; j. menampung dan menindaklanjuti aspirasi dan pengaduan masyarakat; dan k. memberikan pertanggungjawaban secara moral dan politis kepada konstituen di daerah pemilihannya.

e. Kode Etik sebagaimana ditetapkan dalam Peraturan Dewan Perwakilan Rakyat No 1 tahun 2015 tentang Kode Etik Dewan Perwakilan Rakyat Republik Indonesia

Berdasarkan lima pedoman tersebut di atas, maka makna nilai ketuhanan telah dengan nampak nyata meliputi suasana kebatinan yang tentunya wajib untuk diwujudkan dalam perilaku, berfikir, dan bertindak sehingga tercermin dalam setiap keputusan yang diambil. Nilai-nilai ketuhanan dalam bernegara terlihat dari bagaimana Tuhan dipahami dan disadari kehadirannya oleh elite penguasa atau dalam hal ini pembentuk undang-undang, sehingga keberadaan nilai ketuhanan secara substantif dalam produk hukum apakah itu putusan legislasi/regulasi maupun putusan hakim, akan nampak dan tercermin dalam produk undang-undang yang dihasilkan. ${ }^{22}$

22R. William Liddle yang membagi ke dalam dua sudut pandang. Liddle membagi dua cara pandang elite Islam tentang NKRI; yaitu skripturalis dan substansialis. Bagi skripturalis simbol Islam harus tampil aktual dalam setiap kegiatan kenegaraan, seperti tuntutan pemberlakuan syariat Islam melalui undang-undang atau peraturan daerah. Sementara Bagi substansialis, nilainilai etik Islam: kejujuran, keadilan, bersih, hidup tertib, sehat, gotong-royong atau taawun 
Basis nilai ketuhanan, yang tertanam dalam diri pengembang hukum dan pembentukan undang-undang akan mendorong eksistensinya untuk selalu total dalam melakukan penemuan-penemuan hukum (ijtihad al hukmi) yang obyektif untuk diterapkan pada dinamika dan pembentukan peraturan perundang-undangan. Nilai-nilai Pancasila diakomodir dengan sila pertama "Ketuhanan yang Maha Esa", harus menjadi landasan bagi kebijakan politik dan hukum yang berbasis moral agama; sila kedua, "Kemanusiaan Yang Adil dan Beradab" menjadi landasan kebijakan politik dan hukum yang menghargai dan melindungi hak-hak asasi manusia yang nondiskriminatif; sila ketiga, "Persatuan Indonesia" menjadi landasan kebijakan politik hukum untuk mempersatukan seluruh unsur bangsa dengan ikatan primordialnya masing-masing; sila keempat, "Kerakyatan Yang Dipimpin oleh Hikmat Kebijaksanaan dalam Permusyawaratan / Perwakilan, menjadi landasan kebijakan politik dan hukum yang meletakkan kekuasaan di bawah kekuasaan rakyat (demokrasi); dan sila Keadilan Sosial Bagi Seluruh Rakyat Indonesia, menjadi landasan kebijakan politik dan hukum dalam hidup bermasyarakat yang berlandaskan keadilan sosial sehingga mereka yang lemah secara sosial dan ekonomis tidak ditindas oleh mereka yang kuat secara sewenang-wenang. ${ }^{23}$ Untuk memperjuangkan nilai ketuhanan tersebut bukanlah pekerjaan yang ringan, mengingat hegemoni paradigma positifistik dan merasuknya paham kapitalisme di masyarakat Indonesia dan khususnya para penyelenggara negara utamanya para pembentuk undang-undang.

Kondisi demikian sejalan dengan pernyataan Ahmad Basarah Menyatakan ${ }^{24}$ sebagai bagian dari subyek (wakil Ketua MPR RI) legislator: "Kita berharap para pembentuk hukum dapat kembali kepada falsafah bangsa sendiri dengan menjadikan Pancasila sebagai bintang pemandu yang memberikan pedoman dan bimbingan dalam semua kegiatan legislasi, memberi isi kepada tiap peraturan perundang-undangan serta kerangka yang membatasi ruang gerak isi peraturan perundang-undangan itu. Pancasila sebagai ideologi dinamis memang dapat berkembang mengikuti konteks jamannya, akan tetapi falsafah dasarnya harus bersifat tetap menurut maksud para Pendiri Negara." Berdasarkan Pernyataan tersebut menunjukkan

adalah inti-isi praktik bernegara walaupun tanpa simbol formal Islam. R. William Liddle, "Skripturalisme Media Dakwah: Suatu Bentuk Pemikiran dan Aksi Politik Islam Masa Orde Baru", dalam Ulumul Quran Nomor 3, Vol IV, 1993, (Jakarta: LSAF), hlm 53-65

23 M. Mahfud, MD, Membangun Politik Hukum, Menegakkan Konstitusi, Jakarta, Rajawali Press, 2010, hlm. 17-18.

24 Makal;ah Seminar Legislatif yang diselenggarakan Dewan Perwakilan Mahasiswa (DPM) Fakultas Hukum Universitas Merdeka Malang, pada hari Sedlasa tanggal 17 April 2020 dengan tema "Pancasila Sumber Segala Sumber Hukum Negara", baca https://www.gatra.com/detail/news/317967-Ahmad-Basarah:-Pancasila-Belum-DigunakanSebagai-Sumber-Pembentukan-Hukum.diakses tanggal 21 Agustus 2020 jam 11.23. 
kegelisahan dan potret pembentukan Peraturan Perundang-Undnagan selama ini telah menyimpang dari falsafah bangsa yaitu Pancasila.

Hal yang sama juga dikemukakan Amin Rais sebagai solusi terhadap problematika tersebut diatas yaitu menawarkan konsep tauhid sosial, konsep ini patut untuk mendapatkan respon dalam dinamika atau proses politik dalam pembentukan undang-undang, menurut konsep tauhid sosial, dalam pendapat Amin Rais, pada ranah politik dibagi dua jenis politik, yaitu politik kualitas tinggi (high politic) dan politik kualitas rendah (low politic). Politik kualitas tinggi yang dikenal dalam istilah lain adalah adi luhung, didasarkan kepada konsep tauhid sebagai prinsip utamanya. Dalam politik kualitas tinggi, seorang politisi harus bersandar kepada moralitas dan etika yang bersumber kepada prinsip tauhid. ${ }^{25}$

Dalam pandangan Amin Rais dengan mengusung paradigma High politic, sebagai cara pandang baru untuk menempatkan politik sebagai sarana dakwah dan banyak mengacu kepada moralitas keagamaan, lebih lanjut dijabarkan etika tauhid tidak hanya dalam dimensi monoteisme sebagaimana difahami oleh banyak orang, namun lebih luas dalam dimensi sosial guna membumikan pesan-pesan Illahi yang dituangkan dalam ajaran Islam. ${ }^{26}$ Supaya, etika tauhid mampu menginspirasi tindakan rasional manusia dalam menjalakan tugas dan kewajibannya, baik sebagai anggota maupun pemimpin Dewan Perwakilan Rakyat .

Berdasarkan konsep politik tauhid sosial tersebut, sejalan dan memberi makna serta merupakan implementasi semangat Frasa "Dengan Rahmat Tuhan Yang Maha Esa ${ }^{27}$ dalam setiap produk hukum / peraturan perundangundangan sebagai syarat formal dari undang-undang, Frasa "Dengan Rahmat Tuhan Yang Maha Esa" memberikan makna sangat penting dan mendasar bahwa tugas legislator adalah tugas yang sangat luhur sebagai penegak hukum dan keadilan yang wajib dipertanggungjawabkan, utamanya kepada Tuhan Yang Maha Esa, yang sudah tentu untuk mencapainya dipersyaratkan sifat-sifat yang harus dimiliki oleh seorang legislator.

Dengan menghayati/menjiwai hakikat Rahmat Tuhan Yang Maha Esa yang berarti memenuhi tuntunan wahyu Tuhan, barulah orang (anggota DPR) akan terbebas dari "nilai/kekuasaan subjektif" berupa hawa nafsu ; kebencian

${ }^{25}$ Amien Rais, Cakrawala Islam: Antara Cita dan Fakta, (Bandung: Mizan, 1999), hlm. 18 ${ }^{26} \mathrm{Ibid}$.

${ }^{27}$ Retno Saraswati, Guru Besar Ilmu Hukum Universitas Diponegoro Semarang, mengatakan penempatan kalimat 'Dengan Rahmat Tuhan Yang Maha Esa' pada setiap perundang-undangan bermakna nilai-nilai ketuhanan seharusnya menjiwai proses pembentukan dan materi UndangUndang tersebut. (Baca: Irah-Irah, Kepala Putusan yang Bermakna Sumpah). Sayangnya, kalimat bernilai ketuhanan itu terkesan hanya sekadar pemuatan formal dalam setiap Undang-Undang. "Isinya sering tidak mencerminkan nilai-nilai ketuhanan," 
golongan ; ataupun hubungan kekerabatan (nepotisme/favoritism). ${ }^{28}$ Para pembentuk undang-undang akan terhindar dari politik kualitas rendah yaitu menempatkan cara berfikir politiknya untuk kepentingan dirinya, kepentingan sesaat, dan menghalalkan segala cara untuk melanggengkan kekuasaan, dalam dimensi ini, politisi selalu menanggalkan prinsip-prinsip dasar moralitas berpolitik yang luhur dengan cara mengingkari amanah rakyat, melepaskan diri dari tanggung jawab, dan mengedepankan semangat tribalisme maupun egosentrisme kelompoknya. ${ }^{29}$

\section{Kesimpulan}

Pembentuk Peraturan Perundang-undangan (legislator), terindikasi mengabaikan nilai Pancasila sebagai fundamental nilai, utamnaya nilai Ketuhanan, selain itu Pembentuk Undang-undang memperlihatkan adanya problematika paradigmatik dan krisis kesadaran etis dalam pembentukan dan penegakan hukum di Indonesia. Sehingga yang muncul adalah pembangunan hukum dan penegakan hukum yang stagnan, sentralistik, koruptif dan sangat jauh dari nilai-nilai Ketuhanan, dan humanis, dan jauh dari tercapainya keadilan sosial. Nilai Ketuhana sebagai nilai fundamental dari Pancasila sudah seharusnya diakomodir dan menjadi landasan bagi legislator dalam menjalankan fungsi dan tugasnya dalam pembentukan hukum atau undangundang dan di transformasikan dalam produk undang-undang yang dibentuknya, sehingga akan melahirkan undang-undang yang efektif dan berdemensi ketuhanan, kemanusian, persatuan dan berkeadilan social.

\section{Refrences}

Abdul Hakim G. Nusantara. 1988 Politik Hukum Indonesia, (Jakarta: Yayasan Lembaga Bantuan Hukum Indonesia) Amien Rais. 1999. Cakrawala Islam: Antara Cita dan Fakta, (Bandung: Mizan)

\footnotetext{
${ }^{28}$ Tuntunan Tuhan antara lain menyatakan: an-Nisa' ayat 58: "Apabila kamu menghukum di antara manusia, maka hukumlah dengan adil; An-Nisaa': 135 : jadilah kamu orang yang benarbenar menegakkan keadilan, menjadi saksi karena Allah, walaupun terhadap dirimu sendiri, ibu bapakmu dan kaum kerabatmu; janganlah kamu mengikuti hawa nafsumu karena ingin menyimpang dari kebenaran/keadilan; "Al-Maidah:8- "Janganlah kebencianmu kepada suatu kaum / golongan, mendorong kamu berlaku tidak adil;" Asy- Syuura:15 - "Perlakuan adil wajib ditegakkan terhadap siapa saja, kendati terhadap orang yang tidak seagama;" Selanjutnya dalam prakata oleh Bandung, 20 Mei 1963. NEGARA dalam PANCASILA, Mr. Soediman Kartohadiprodjo yang disampaikan sebagai sumbangsih pada "Seminar Hukum Nasional I 1963" bahwa Manusia ini ditakdirkan oleh Tuhan untuk hidup bersama dengan sesamanya manusia, dengan diperlengkapi dengan alat-alat yang diperlukan (Sila Pertama, Kedua dan Ketiga).

${ }^{29}$ Fathorrahman, “Paradigma Politik Profetik: Sebuah Pembacaan Ideografik Terhadap Politik Adiluhung Amien Rais", IN RIGHT Jurnal Agama dan Hak Azazi Manusia Vol. 4, No. 1, November 2014, hlm. 126
} 
Bayu Dwi Anggono, Perkembangan Pembentukan Undang-Undang di Indonesia, Jakarta: Konstitusi Press, 2014

Faisal. 2010. Menerobos Positivisme Hukum, (Yogyakarta: Rangkang Education)

Erina Pane \& Adam Muhammad Yanis. Reconstruction of Mining Policies on Justice in Lampung Province, Jurnal Bestuur Vol. 8, Issue 2, December, 2020.

Saputra, Rian, Development of Creative Industries as Regional Leaders in National Tourism Efforts Based on Geographical Indications, Jurnal Bestuur Vol. 8, Issue 2, December, 2020.

Luthviati, R.D, The Role of Local Governments in the Defense of Leading Products, Jurnal Bestuur Vol. 8, Issue 2, December, 2020.

Ach.Tahir, Iswantoro, Siti Fatimah, Resti Dian Luthviati, Rian Saputra, Abdul Kadir Jaelani, The Model Of Criminal Policy To Customary Law Society After Decision Of The Constitutional Court Of The Republic Of Indonesia Number 95/Puu-Xii/2014, International Journal of Advanced Science and Technology Vol. 29, No. 4, (2020).

Ika Khairunnisa Simanjuntak, Pengecualian Rahasia Perbankan untuk Kepentingan Perpajakan di Indonesia, Pena Justisia: Media Komunikasi dan Kajian Hukum, Vol.19, No.1, Juni, 2020

Abdul Kadir Jaelani, I Gusti Ayu Ketut Rachmi Handayani, Lego Karjoko. The Political Law of the Constitutional Court In Canceling the Concept of the Four Pillars as an Pancasila as the State Foundation, Talent Development E Excellence, Vol.12, No.2s, 2020.

Anggri Rudianto, Suhariningsih, Bambang Winarno. Kewenangan Pemegang Protokol Notaris yang Meninggal Dunia untuk Mengeluarkan Salinan Akta dari Minuta Akta yang Belum Lengkap Tanda Tangannya, Pena Justisia: Media Komunikasi dan Kajian Hukum, Vol.19, No.1, Juni, 2020.

Taufiq Taufiq, Sanksi Hukum Terhadap PelakuTindak Kekerasan Terhadap Perempuan dan Anak, Pena Justisia: Media Komunikasi dan Kajian Hukum, Vol.19, No.1, Juni, 2020.

Sugianto, Optimalisasi Kemandirian Kelautan dalam Mewujudkan Pembangunan Budaya Maritim Nasional, Pena Justisia: Media Komunikasi dan Kajian Hukum, Vol.19, No.1, Juni, 2020.

Multimatun Ni'ami, Bisnis Transportasi dalam Pusaran Globalisasi, Pena Justisia: Media Komunikasi dan Kajian Hukum, Vol.19, No.1, Juni, 2020.

Anik Indriono, Implementasi Standar Sumber Daya Manusia dan Pelayanan Minimal Kesehatan di Kota Pekalongan, Pena Justisia: Media Komunikasi dan Kajian Hukum, Vol.19, No.1, Juni, 2020.

Endang Yuliana Susilawati Tabah Budi Prasetyo, Law Compliance Against Perpetrators of Covid-19's Forced Retrieval, Pena Justisia: Media Komunikasi dan Kajian Hukum, Vol.19, No.1, Juni, 2020.

Ach.Tahir, Iswantoro, Siti Fatimah, Resti Dian Luthviati, Rian Saputra, Abdul Kadir Jaelani, The Model Of Criminal Policy To Customary Law Society After 
Decision Of The Constitutional Court Of The Republic Of Indonesia Number 95/Puu-Xii/2014, International Journal of Advanced Science and Technology Vol. 29, No. 4, (2020).

Siti Fatimah, Iswantoro, Udiyo Basuki, Rian Saputra, Abdul Kadir Jaelani. The Public Policy Of Local Government In Protecting Geographic Indication As A Leading Regional Product, International Journal of Advanced Science and Technology Vol. 29, No. 4, (2020).

Lego Karjoko, Zaidah Nur Rosidah, I Gusti Ayu Ketut Rahmi Handayani "Refleksi Paradigma Ilmu Pengetahuan Bagi Pembangunan Hukum Pengadaan Tanah", Bestuur, Volume 7, Nomor 1 Tahun 2019.

I Gusti Ayu Ketut Rachmi Handayani, Lego Karjoko, Abdul Kadir Jaelani, "Model Pelaksanaan Putusan Mahkamah Konstitusi yang Eksekutabilitas Dalam Pengujian Peraturan Perundang-Undangan di Indonesia", Bestuur, Volume 7, Nomor 1 Tahun 2019.

Zaidah Nur Rosidah, "Coherence of the Rules of Sharia Against Pancasila", Bestuur, Volume 8, Nomor 1 Tahun 2020.

Abdul Kadir Jaelani, I Gusti Ayu Ketut Rachmi Handayani, Lego Karjoko. The Political Law of the Constitutional Court In Canceling the Concept of the Four Pillars as an Pancasila as the State Foundation, Talent Development $\mathcal{E}$ Excellence, Vol.12, No.2s, 2020. 